University of Nebraska - Lincoln

DigitalCommons@University of Nebraska - Lincoln

USGS Staff -- Published Research

US Geological Survey

2014

\title{
Merging remote sensing data and national agricultural statistics to model change in irrigated agriculture
}

Jesslyn F. Brown

Earth Resources Observation and Science Center, jfbrown@usgs.gov

Md Shahriar Pervez

Earth Resources Observation and Science Center, Sioux Falls

Follow this and additional works at: http://digitalcommons.unl.edu/usgsstaffpub

Part of the Geology Commons, Oceanography and Atmospheric Sciences and Meteorology Commons, Other Earth Sciences Commons, and the Other Environmental Sciences Commons

Brown, Jesslyn F. and Pervez, Md Shahriar, "Merging remote sensing data and national agricultural statistics to model change in irrigated agriculture" (2014). USGS Staff-- Published Research. 913.

http:// digitalcommons.unl.edu/usgsstaffpub/913

This Article is brought to you for free and open access by the US Geological Survey at DigitalCommons@University of Nebraska - Lincoln. It has been accepted for inclusion in USGS Staff -- Published Research by an authorized administrator of DigitalCommons@University of Nebraska - Lincoln. 


\title{
Merging remote sensing data and national agricultural statistics to model change in irrigated agriculture
}

\author{
Jesslyn F. Brown ${ }^{a, *}$, Md Shahriar Pervez ${ }^{b}$ \\ ${ }^{a}$ U.S. Geological Survey, Earth Resources Observation and Science Center, Sioux Falls, SD 57198, USA \\ ${ }^{\mathrm{b}}$ ASRC Federal InuTeq, U.S. Geological Survey, Earth Resources Observation and Science Center, Sioux Falls, SD 57198, USA
}

\section{A R T I C L E I N F O}

\section{Article history:}

Received 22 April 2013

Received in revised form 24 December 2013

Accepted 11 January 2014

Available online 20 February 2014

\section{Keywords:}

Irrigated agriculture

Remote sensing

Moderate Resolution Imaging

Spectroradiometer (MODIS)

Normalized Difference Vegetation Index

High Plains Aquifer

Geospatial model

\begin{abstract}
A B S T R A C T
Over 22 million hectares (ha) of U.S. croplands are irrigated. Irrigation is an intensified agricultural land use that increases crop yields and the practice affects water and energy cycles at, above, and below the land surface. Until recently, there has been a scarcity of geospatially detailed information about irrigation that is comprehensive, consistent, and timely to support studies tying agricultural land use change to aquifer water use and other factors. This study shows evidence for a recent overall net expansion of 522 thousand ha across the U.S. (2.33\%) and 519 thousand ha $(8.7 \%)$ in irrigated cropped area across the High Plains Aquifer (HPA) from 2002 to 2007. In fact, over 97\% of the net national expansion in irrigated agriculture overlays the HPA. We employed a modeling approach implemented at two time intervals (2002 and 2007) for mapping irrigated agriculture across the conterminous U.S. (CONUS). We utilized U.S. Department of Agriculture (USDA) county statistics, satellite imagery, and a national land cover map in the model. The model output, called the Moderate Resolution Imaging Spectroradiometer (MODIS) Irrigated Agriculture Dataset for the U.S. (MIrAD-US), was then used to reveal relatively detailed spatial patterns of irrigation change across the nation and the HPA. Causes for the irrigation increase in the HPA are complex, but factors include crop commodity price increases, the corn ethanol industry, and government policies related to water use. Impacts of more irrigation may include shifts in local and regional climate, further groundwater depletion, and increasing crop yields and farm income.
\end{abstract}

Published by Elsevier Ltd.

\section{Introduction}

Intensification of agricultural land use through irrigation influences crop yields, boundary layer energy exchange, groundwater recharge, regional climate, and water quality (Adegoke et al., 2003; Matson et al., 1997; Puma and Cook, 2010; Sacks et al., 2009; Scanlon et al., 2007). As of 2007, 22.9 million ha (56.6 million acres) of croplands in the U.S. were irrigated according to the U.S. Census of Agriculture (U.S. Department of Agriculture, 2009a). This represents a modest $2.33 \%$ increase in the area of irrigated crops from 2002 (U.S. Department of Agriculture, 2004). However, regional patterns in gains and losses in irrigated area vary significantly from the national picture.

A large proportion of irrigated cropland in the U.S. is fed by groundwater, in fact the USDA estimates nearly $67 \%$ of the water used to irrigate is provided by groundwater (U.S. Department of Agriculture, 2009b). In the central Great Plains of the U.S. (portions of Colorado, Kansas, Nebraska, New Mexico, Oklahoma, South Dakota, Texas and Wyoming), over six million ha of irrigated

\footnotetext{
* Corresponding author. Tel.: +1 6055946003.

E-mail address: jfbrown@usgs.gov (J.F. Brown).
}

croplands (approximately $26 \%$ of the U.S. total), are primarily fed by groundwater extracted from the High Plains Aquifer (HPA), also known as the Ogallala aquifer. The HPA underlies a $451,000 \mathrm{~km}^{2}$ area and was the most intensively used aquifer in the U.S. in 2000 (Maupin and Barber, 2005). The land cover here is primarily cropland and pasture. Principal irrigated crops include corn (Zea mays), soybeans (Glycine max), cotton (Gossypium hirsutum), alfalfa (Medicago sativa L.), grain sorghum (Sorghum bicolor), and wheat (Triticum spp.) (Dennehy et al., 2002).

Concerns that the widespread practice of irrigation in this region is unsustainable have been expressed since the 1970s (High Plains Study Council, 1982; Peterson and Bernardo, 2003; Sophocleous, 2005). Yet recent studies have indicated expansion in irrigation today (Dennehy et al., 2002; Johnson et al., 2011; Nickerson et al., 2011). This expansion is spatially variable and discontinuous. Since there has been a lack of spatially-detailed data on irrigation status, we see this as a gap needing to be filled. Tracking the locations, geographic area, and timing of agricultural intensification should improve water resource management, advance models of water and energy exchange between the atmosphere and land surface, clarify climate interactions, and reveal effects on ecosystem services (Matson et al., 1997; 
Puma and Cook, 2010; Shiklomanov, 2000; Vörösmarty et al. 2000).

Geospatial irrigation data that is detailed, comprehensive, consistent, and timely is needed to support studies tying agricultural land use change to aquifer water use and other factors. While the USDA publishes county areal irrigation estimates, spatial information is not provided to determine the specific locations of irrigated fields (U.S. Department of Agriculture, 2009a, 2012). Additionally, a handful of studies have produced geospatial irrigation land use data for national, continental, or global domains in the 21 st century, but there are none to date that have a regular (e.g. sub-decadal) repeat cycle, allowing for consistent spatially-detailed tracking of irrigation change (Ozdogan and Gutman, 2008; Thenkabail et al., 2009).

This study shows evidence for a recent overall expansion of 519 thousand ha (8.7\% increase) in irrigated cropped area across the HPA from 2002 to 2007, and by way of detailed geospatial analysis shows sub-county to regional differences in spatial patterns of irrigation change. For this study, we employed a modeling approach implemented at two time intervals (2002 and 2007) for mapping irrigated agriculture across the conterminous U.S. (CONUS). We then utilized this methodology to determine relatively detailed spatial patterns of irrigation change across the HPA. Subsequent change analysis incorporated national-level geospatial models called the Moderate Resolution Imaging Spectroradiometer (MODIS) Irrigated Agriculture Dataset for the U.S. (MIrAD-US) computed for two eras, 2002 (Pervez and Brown, 2010) and 2007. This article summarizes 2007 model results, the change in irrigation from 2002 to 2007 and presents a discussion of possible causes and effects related to the changes in land use associated with irrigated agriculture between 2002 and 2007 within the HPA.

\section{Background}

The first wells installed in the HPA for irrigating crops were dug in the late 1930 s, followed by large increases in drilling especially in the 1950s, 1960s, and 1970s (Nebraska Department of Natural Resources, 2012b). Although the establishment of new irrigation wells appeared to stabilize in the 1980s and 1990s, it appears that expansion of irrigation is occurring again in this century. In Nebraska alone, over 60,000 registered irrigation wells tapped into the HPA between 1972 and 2011 (Nebraska Department of Natural Resources, 2012b). In 2000, total groundwater withdrawals from the HPA were estimated at $17,500 \mathrm{Mgal} /$ day and the majority (97\%) of the total water withdrawn was used for irrigation (Maupin and Barber, 2005).

The states of Nebraska, Texas, and Kansas used $88 \%$ of the HPA total water withdrawals in 2000 almost entirely for irrigated agriculture (Maupin and Barber, 2005). Approximately two thirds of the aquifer's total water storage capacity underlies the state of $\mathrm{Ne}$ braska (Johnson et al., 2011). Furthermore, Nebraska is currently the most intensively irrigated state in the country, surpassing California with the highest number of irrigated ha in 2007 (U.S. Department of Agriculture, 2009a).

In many areas, groundwater withdrawals from the HPA already exceed recharge, causing substantial declines in groundwater levels (Dennehy et al., 2002). Some of the largest groundwater level declines have occurred in southwest Kansas and the panhandle of Texas (see Fig. 2 in McGuire (2011)). Following the large expansion in irrigation in the decades leading up to 1980, decreasing groundwater resources across the HPA and increasing energy costs led to concerns about the sustainability of water use. Multiple studies were initiated; the most comprehensive water policy analysis conducted to date was the High Plains Ogallala Regional Aquifer Study (referred to here as the High Plains Study) completed in
1982 (High Plains Study Council, 1982). The High Plains Study predicted future reductions in irrigated land area and related water use (under its baseline scenario involving no major changes in state water-use regulations), but rather than seeing reductions in the amount of irrigation supplied by the HPA, the most recent decade has seen an expansion in irrigation land use. An expansion in irrigated fields does not necessarily mean a comparable increase in water or energy use, since efficiencies have been gained by technological changes in water delivery mechanisms and management practices (Evans and Sadler, 2008).

\section{Data and methods}

In a prior study, we implemented a geospatial model (Pervez and Brown, 2010) to create a U.S. map of irrigated lands for the year 2002. For the current study, we implemented the model using the same input data types from our prior study but tuned for circa 2007, the target time period. Herein, we provide a brief description of the input data sets and the geospatial model specific to the modeling year. A detailed description of the input data for the model is provided by Pervez and Brown (2010). The method incorporated the following three primary data inputs:

1. USDA county-level irrigation area statistics for 2007 (U.S. Department of Agriculture, 2009a).

2. Annual peak MODIS Normalized Difference Vegetation Index (NDVI) (a proxy for maximum vegetation vigor) for 2007.

3. A land cover mask for agricultural lands derived from NLCD 2006 (Fry et al., 2011).

And the success of the modeling relied on the following three assumptions:

1. Irrigated crops commonly exhibit higher annual peak NDVI values than non-irrigated crops in the same local area.

2. The growing season peak NDVI, at any time it occurs, will vary for each crop and for each geographic region of the U.S.

3. The difference in NDVI between irrigated and non-irrigated crops will be enhanced under non-optimal precipitation conditions (e.g., drought).

\subsection{Input data}

\subsubsection{County irrigation statistics}

The USDA Census of Agriculture publishes estimates of irrigated area (in acres) for each of the 3114 counties in the conterminous U.S. every five years and we used these county statistics of irrigated areas for 2002 and 2007 (U.S. Department of Agriculture, 2009a). The Census of Agriculture estimates were derived from data collected from over three million farmers and ranchers primarily through mailout and mailback method supplemented with electronic data reporting, telephone interview and personal enumeration with response rate of $85.2 \%$ for the 2007 Census. The collected data go through intensive quality checking before being used in an extensive process to compute adjusted estimates for the entire country. USDA National Agricultural Statistics Service (NASS) reported the reliability of the 2007 estimates as relative Root Mean Square Error (RMSE) of $0.25 \%$ which has improved from the RMSE of $0.64 \%$ for 2002 Census estimates (U.S. Department of Agriculture, 2009a).

\subsubsection{MODIS annual peak NDVI}

We computed the annual peak (or maximum) NDVI for 2007 from an annual time series of MODIS composited NDVI. The 2007 NDVI source was part of the CONUS 250-m resolution MODIS time 
series produced at the USGS EROS Center (Jenkerson et al., 2010). The time-series NDVI represented the progression of vegetation condition, and the peak or maximum from the annual time series was used in the model as a proxy measure of the most vigorous state of the vegetation within the year. This model only required a single peak NDVI regardless of its phenological timing. Irrespective of irrigation status, every land pixel had a peak NDVI, and based on our investigations the magnitude of peak NDVI values differed depending on the irrigation status of the vegetation. Previous studies indicated that NDVI positively correlates with the availability of moisture for the vegetation (Ji and Peters, 2003; Kawabata et al., 2001; Rundquist et al., 2000; Wang et al., 2003; Wulder et al., 2004), and most irrigated crops will have higher peak NDVI compared to the peak NDVI from the same crop without irrigation (Aparicio et al., 2000; Pervez and Brown, 2010; Wardlow and Egbert, 2008). Within the MIrAD model, pixels with a comparatively higher peak NDVI typically indicate positive irrigation status within the same county area (i.e., fields experiencing common climate conditions).

We selected the MODIS sensor as the source for the peak NDVI as this sensor collects frequent time-series observations of the earth surface with global coverage at a sufficient spatial detail (250-m resolution) to capture most of the irrigated patches in the U.S. agricultural landscape (Townshend and Justice, 2002). The MIrAD-US spatial units have the inherent resolution of the $250-\mathrm{m} \times 250-\mathrm{m}$ MODIS pixels. Each pixel represents 6.25 ha on the ground. Field size had an influence on the accuracy of our methodology to map irrigated lands where a field unit was less than 6.25 ha. Field sizes across the HPA are generally larger than 6.25 ha. For example, in Kansas, field sizes commonly range from 65 to 245 ha (or 10 to $39250 \mathrm{~m}^{2}$ pixels respectively) (Wardlow and Egbert, 2008).

\subsubsection{Land cover}

Consistent with the 2002 MIrAD (Pervez and Brown, 2010), two land cover classes [pasture/hay (81) and cultivated cropland (82)] were extracted from the 2006 NLCD (Fry et al., 2011) to restrict the MIrAD model selection of irrigated pixels for 2007. The land cover mask was crucial as previous studies show that annual peak NDVI from forest and woody wetlands pixels could potentially be higher than the annual peak NDVI from croplands (Brown et al., 2009). Accurate delineation of irrigated pixels within the agricultural landscape thus depends on the classification of the above two classes in the NLCD. The NLCD is the best possible single source land cover available at a national scale that is closely synchronized with the Census of Agriculture (within one year). The 2006 NLCD Level II (16 land cover classes) overall accuracy was $78 \%$, with Level II user's accuracy exceeding $80 \%$ for the cropland class used in our mask.

Because the land cover mask plays a significant role in the MIrAD-US model for 2002 and 2007, changes in this mask (NLCD 2001 and 2006) influences the change in irrigated agriculture discussed in this study. Both the 2001 and 2006 NLCD were developed under similar protocols; however recent NLCD science efforts are evolving with the shift in the emphasis from characterizing discrete snap shots of land cover in time to monitoring land cover change over time. Subsequently, a national change map included in 2006 NLCD showed changes between 2001 and 2006 distinguishing national areal declines in pasture/hay and cultivated crops of $1.05 \%$ (578,000 ha) and 0.15\% (193,300 ha), respectively (Fry et al., 2011). Although from a different source, the Agricultural Census statistics showed a net decrease in total croplands from 2002 to 2007 of over 14 million ha and showed an increase in irrigated areas by 2.3\% (521,263 ha) between 2002 and 2007 (U.S. Department of Agriculture, 2004, 2009a). In 2007, there were less candidate pixels in cropland and pasture in NLCD than in 2002 available to be identified as irrigated pixels but resulting in larger irrigated areas nationally.

\subsection{Geospatial model}

The geospatial model employed the same method used by Pervez and Brown (2010) to map 2002 irrigated areas but forced with 2007 MODIS annual peak NDVI data, 2006 NLCD data, and 2007 Census of Agriculture irrigation statistics to map 2007 irrigated areas. A detailed description including how the geospatial model works along with a process diagram is provided by Pervez and Brown (2010). In brief, the model was executed on a county spatial domain by extracting and building a ranked list of unique annual peak NDVI values from MODIS peak NDVI data layer masked by NLCD data for agricultural land classes only. Starting with the highest ranked peak NDVI, the area of the corresponding peak NDVI value cells was computed and compared with the USDA irrigation area statistics for that county. The same process is repeated for each peak NDVI values in a descending order until the accumulated area closely matches the county area estimate from the Census. The corresponding pixels that contribute to the matched area were identified as irrigated for the county. In a final post-processing step all lone (single) pixels were spatially filtered from the irrigated area map.

Climatology played an important role shaping the differences in annual peak NDVI between irrigated and non-irrigated cropland. Adequate moisture from precipitation available to non-irrigated crops can increase the peak annual NDVI value, potentially narrowing the difference in peak NDVI between irrigated and non-irrigated crops making them difficult to separate. In contrast, lack of moisture from low precipitation available to non-irrigated crops will negatively impact the annual peak NDVI value and widen the difference between peak NDVI from irrigated and non-irrigated crops making to the two more separable. Fig. 1 shows a time series of NDVI for sample irrigated and non-irrigated pixels in southeast Nebraska (Clay County). This six year time series shows consistency in the maximum NDVI for the irrigated pixel and variability in the peak for the non-irrigated pixel. Of note, 2002 shows the greatest contrast in the annual peak NDVI between the irrigated and non-irrigated pixels corresponding to local drought. The annual average precipitation in the U.S. in 2007 was $733 \mathrm{~mm}, 7 \mathrm{~mm}$ less than the long term (1901-2000) mean precipitation (National Oceanic and Atmospheric Administration, 2007). Although 2007 was not significantly drier than average, sporadic rainfall during spring and summer produced wide spread moderate to extreme drought conditions in much of Southeast and the West (Jones, 2010; Migliaccio, 2008; National Oceanic and Atmospheric Administration, 2007).

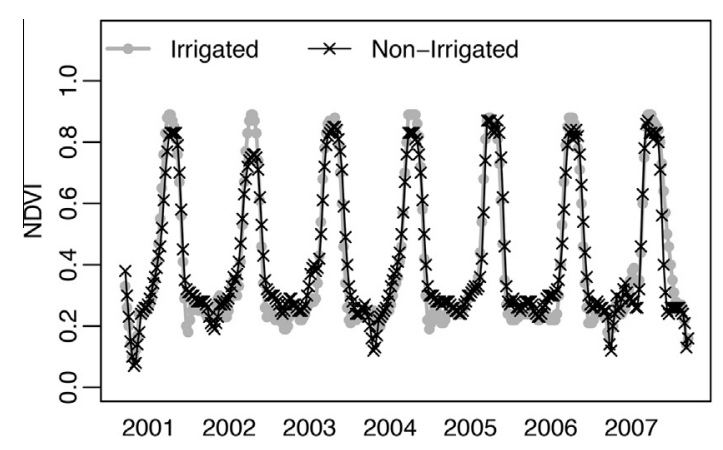

Fig. 1. Time series NDVI for irrigated and non-irrigated pixels in Clay County, Nebraska. 


\section{Results}

\subsection{Accuracy assessment}

Protocols for accuracy assessment of MIrAD-US 2007 are built upon the MIrAD-US 2002 (Pervez and Brown, 2010) accuracy assessment. Two reference data sets (California and the Great Plains) used to validate MIrAD-US 2002 were also used to validate MIrAD-US 2007. We obtained an additional spatial irrigation data set for 2006 for Idaho from the Idaho Department of Water Resources (IDWR).

\subsubsection{Accuracy assessment of 2007 MIrAD-US in California}

Field boundaries for 19 counties in California surveyed by California Department of Water Resources (DWR) over five-year period (2000-2004) for their land use and irrigation status information were used as the ground reference (Pervez and Brown, 2010). We converted field polygons into grids using an irrigation attribute ( 1 for irrigated and 0 for non-irrigated) matching the spatial properties (projection, extent, and cell size) of the 2007 MIrAD-US so that both data products fully overlay each other on a cell-by-cell basis. In contrast to the 2002 MIrAD-US assessment, we employed raster overlay to compare 2007 MIrAD-US with DWR fields on cellby-cell basis, and generated an error matrix to analyze the agreement between the data sets.

Table 1 shows overall accuracy of $92 \%$ with Kappa index of 0.75 suggestive of good agreement with DWR irrigated fields. However, relatively high omission error of $27 \%$ for irrigated class indicates probable omission of irrigated areas in 2007 MIrAD-US, similarly to the 2002 MIrAD-US (Pervez and Brown, 2010). Differences in spatial resolution and underlying identification method for irrigated areas used by the DWR and in the MIrAD-US model was the prime reason. The irrigated areas identified in the California DWR field map were not constrained by their size, whereas irrigated areas in MIrAD-US model were constrained by a minimum area of $250-\mathrm{m} \times 250-\mathrm{m}$ (6.25 ha) due to the source MODIS annual peak NDVI input. The DWR field map had 22\% larger area of irrigated agriculture compared to 2007 MIrAD-US for these 19 counties. There was a temporal mismatch between the DWR field data and 2007 MIrAD-US, but more recent field data sets for California were not available.

Although the overall accuracy of the 2007 MIrAD-US with DWR field map remains the same as the 2002 results at $92 \%$, the producer's accuracy for irrigated class for the later MIrAD-US map is lower. The larger time lag between the DWR survey period and the 2007 MIrAD-US compared to the 2002 MIrAD-US might have contributed to relatively low producer's accuracy and comparatively higher omission error.

\subsubsection{Accuracy assessment of 2007 MIrAD-US in the Great Plains}

We used a total of 336 sites across the Great Plains region surveyed by University of North Dakota in August, 2006 to assess the accuracy of 2007 MIrAD-US in the Great Plains region. Details about these survey sites along with their spatial distribution across the Great Plains are provided by Pervez and Brown (2010). For consistency, we adopted the same method that was used to assess the accuracy of 2002 MIrAD-US, but for 2007 assessment, we generated the error matrix by polygons only.

The 2007 MIrAD-US agreed reasonably well with ground surveyed irrigated area information with an overall accuracy of $89 \%$ and Kappa index of 0.70 (Table 2). The 2007 MIrAD-US exhibited a higher agreement with the surveyed Great Plains ground samples compared to the 2002 MIrAD-US. The nominal temporal difference between the 2007 MIrAD-US and the survey year (2006) might have led to better match the ground reference information.

\subsubsection{Accuracy assessment of 2007 MIrAD-US in the Eastern Snake River Plain Aquifer (ESPA)}

The ESPA is one of the most well managed irrigated areas in the country. The IDWR provided vector coverage of fields with irrigation status as a polygon attribute for 2006. IDWR used a 3-step process to map irrigated areas. The process started with extensive editing of vectors in the Farm Service Agency Common Land Unit (CLU) data. The CLU data do not contain any attributes-only vectors. To assign irrigation status for each polygon, IDWR used growing season Landsat imagery and digital aerial photography. We converted the IDWR irrigated lands vector database to raster matching the spatial resolution of 2007 MIrAD-US and assigned 1 or 0 for irrigated and non-irrigated class based on the irrigation status information. This ESPA irrigated lands raster layer was compared with the 2007 MIrAD-US data on a cell-by-cell basis and an error matrix was produced (Table 3 ).

The ESPA assessment showed good agreement between the 2007 MIrAD-US and the reference area map with $94 \%$ overall accuracy and a kappa statistic of 0.77 . Out of the three accuracy assessment regions, the ESPA assessment shows the best agreement. The

Table 1

Error matrix summary of irrigated and non-irrigated category between MIrAD-US 2007 and DWR fields map for California.

\begin{tabular}{|c|c|c|c|c|c|c|}
\hline Category & Producer's accuracy & Errors of omission & User's accuracy & Errors of commission & Overall accuracy & Kappa stat \\
\hline Irrigated & 0.73 & 0.27 & 0.89 & 0.11 & 0.92 & 0.75 \\
\hline Non-irrigated & 0.98 & 0.02 & 0.93 & 0.07 & & \\
\hline
\end{tabular}

Table 2

Error matrix summary of irrigated and non-irrigated categories between 2007 MIrAD-US and UND ground observation sites for the Great Plains.

\begin{tabular}{|c|c|c|c|c|c|c|c|}
\hline Comparison type & Category & Producer's accuracy & Errors of omission & User's accuracy & Errors of commission & Overall accuracy & Kappa stat \\
\hline \multirow[t]{2}{*}{ By polygons } & Irrigated & 0.92 & 0.08 & 0.94 & 0.06 & 0.89 & 0.70 \\
\hline & Non-irrigated & 0.80 & 0.20 & 0.73 & 0.25 & & \\
\hline
\end{tabular}

Table 3

Error matrix summary of irrigated and non-irrigated categories between 2007 MIrAD-US and IDWR irrigated area information for the ESPA.

\begin{tabular}{|c|c|c|c|c|c|c|c|}
\hline Area & Category & Producer's accuracy & Errors of omission & User's accuracy & Errors of commission & Overall accuracy & Kappa stat \\
\hline \multirow[t]{2}{*}{ ESPA } & Irrigated & 0.74 & 0.26 & 0.86 & 0.14 & 0.94 & 0.77 \\
\hline & Non-irrigated & 0.98 & 0.02 & 0.95 & 0.05 & & \\
\hline
\end{tabular}


ESPA region is characterized by highly mechanized large scale irrigation management and is geographically located in a semi-arid and fairly homogeneous landscape. This setting is well-suited for the operation of the MIrAD model. Despite a high overall agreement, the producer's accuracy for irrigated land was only $74 \%$. This is mostly because of the fine spatial detail in the ESPA irrigated lands database, which identified irrigation status for every polygon regardless of their size, whereas the MIrAD-US 2007 map is constrained by its spatial resolution of $250-\mathrm{m} \times 250-\mathrm{m}$.

\subsubsection{Accuracy, errors, and uncertainty}

A primary goal of accuracy assessment for a map like the MIrAD-US is to promote understanding of the validity of the land use information, both categorically and across the spatial domain of the map. Although the average accuracy of the irrigated class for the three regions we assessed is relatively high $(0.80,0.90$, and 0.92 for producer's accuracy, user's accuracy, and overall accuracy, respectively), these accuracy assessments are spatially restricted and therefore, somewhat limited. A comprehensive accuracy assessment was not done mainly because wall-to-wall field level ground irrigation data was not accessible to our project.

Uncertainties are inherent in all geospatial data and data products and the MIrAD-US is no exception. Uncertainties can be attributed due to positional accuracy, spatial resolution, attribute accuracy, data completeness, logical consistency, currency, credibility, subjectivity and interrelatedness (Kraak and Ormeling, 1996; Viard et al., 2011). It is often neither possible nor desirable to quantify and eliminate many of these uncertainties because resources are always limited and must be used effectively (Van Rompaey and Govers, 2002). However it is important to communicate to the user the underlying uncertainties in input data and final product which is critical to draw appropriate spatial decisions. The MIrAD-US model input parameters that are likely to contribute mostly to the uncertainties associated with the MIrAD-US are discussed below.

The county-level irrigated statistics provided by the USDA Census of Agriculture provided the spatial area target for the MIrAD-US model. The statistics, collected and processed by NASS using sampling procedures, are subjected to sampling and nonsampling errors affecting the "precision" of the estimates. Sampling error occurred because a complete Census was not taken and nonsampling error was caused by an inability to obtain correct information from each person sampled, differences in interpreting questions, and mistakes in processing the data. As the irrigated area statistic was one of the key variables in MIrAD-US model, the reported RMSEs of $0.64 \%$ and $0.25 \%$ for 2002 and 2007 precision estimates in irrigated are statistics propagated uncertainty in the final MIrAD-US maps.

The two additional model input variables, the NLCD and the MODIS annual peak NDVI, contribute additional sources of uncertainty. We used the pasture/hay and cultivated crop classes of the NLCD to constrain the selection of irrigated areas within agricultural lands. The original $30-\mathrm{m}$ resolution land cover data were resampled to $250-\mathrm{m}$ to match the MODIS peak NDVI data. The resampling introduced errors in land cover because large proportion errors can arise as landscapes are represented at increasingly coarser scale (Moody and Woodcock, 1994) and such errors have significant implications for activities that rely on land cover datasets derived from remote sensing (Moody and Woodcock, 1995). As dominant land cover type was considered for each 250-m aggregated land cover cell, there were uncertainties related to mixed land cover pixels. The 2001 and 2006 NLCD maps (Wickham et al., 2010, 2013) have reported $85 \%$ and $84 \%$ level 1 accuracies and we found modest agreement between county farmland statistics and county agricultural land from NLCD (Pervez and Brown, 2010). This attributed uncertainty in the agricultural land cover mask used in the MIrAD-US modeling which potentially propagated to the final MIrAD-US maps.

It is also possible that non-irrigated crops may have higher annual peak NDVI than irrigated crops leading to uncertainty, however, our investigations showed this to be fairly rare. NDVI smoothing was implemented across all time-series data irrespective of land cover types.

Finally, the difference in the spatial detail of the target land use versus the resolution of the input geospatial data is another potential source of uncertainty. We mapped irrigated areas as binary layer at $250-\mathrm{m} \times 250-\mathrm{m}(6.25 \mathrm{ha})$ resolution and the occurrence of subpixel fractions of irrigation was not investigated. Although irrigated fields were generally large across conterminous U.S., small irrigated fields ( $<6 \mathrm{ha}$ ) were not regularly resolved within the pixel resolution of the MODIS data which attributed uncertainty in the final MIrAD-US maps.

\subsection{Change in irrigated area}

\subsubsection{Change in irrigated lands across the conterminous U.S. from 2002 to 2007}

Consistent with MIrAD-US 2002 model output, the MIrAD-US 2007 model produced two-class land use data representing the spatial distribution of irrigated agriculture driven by statistics in the 2007 Census of Agriculture at 250-m resolution (Fig. 2), where $100 \%$ of each $250-\mathrm{m} \times 250-\mathrm{m}$ cell is identified as either irrigated or non-irrigated. Sub-pixel irrigation status was not addressed by the MIrAD methodology. Fig. 2 shows areas of change and no change in irrigation status between 2002 and 2007. Across the conterminous U.S., irrigated areas showed a net increase of around 3\%. Approximately $60 \%$ of the irrigated areas remained unchanged (in green) between these periods, $43 \%$ were newly identified in 2007, and $40 \%$ were identified as lost from 2002 (Table 4). The blue class (new in 2007) shows pixels that were identified as irrigated in 2007 but were not identified as irrigated in 2002. The red class (lost from 2002) shows areas identified as irrigated in 2002 but not identified as irrigated in 2007.

Table 4 shows areal statistics for the 14 states that each had over half a million ha of irrigated agriculture in 2007 listed in descending order by irrigated area. The top ten states (Nebraska, California, Texas, Arkansas, Idaho, Kansas, Colorado, Montana, Oregon, and Washington.) accounted for $72 \%$ of the total irrigated area and showed substantial spatial consistency in irrigation between 2007 and 2002 (Fig. 2: in green). In these ten states, 67\% of the irrigated areas remained unchanged. The MIrAD approach identified irrigation status, but a change in irrigation status does not necessarily identify a change (presence or absence) in irrigation equipment. Irrigation loss or gain from 2002 to 2007 could result from misidentification of irrigation status in either model year or might simply be a matter of local land use decisions (e.g., change in irrigation water application due to rising or falling water costs, change in cropping practices, leaving fields fallow, etc.). Among the major irrigated states, Nebraska-the state with the largest area of irrigation in 2007-showed the most increase in area from 2002 to 2007 . Over 1.3 million ha of new irrigated areas were identified in 2007 in Nebraska, a net $16.3 \%$ increase.

Along the West coast, California (second only to Nebraska in the number of irrigated ha) lost over 750,000 ha of irrigated lands between 2002 and 2007 (Table 4). This represented a 7.7\% net loss of irrigated area in California, the majority of which occurred in the San Joaquin Valley. Fresno County alone lost 50,950 ha of irrigated area in 2007. Further north, Oregon and Washington showed moderate stability in irrigated lands with $63 \%$ and $65 \%$ unchanged area, respectively. However, there was around $5.2 \%$ net loss in irrigated area in Washington, and majority of these losses were from Lewis, Pierce and Thurston counties in the east and Douglas, Lincoln and 


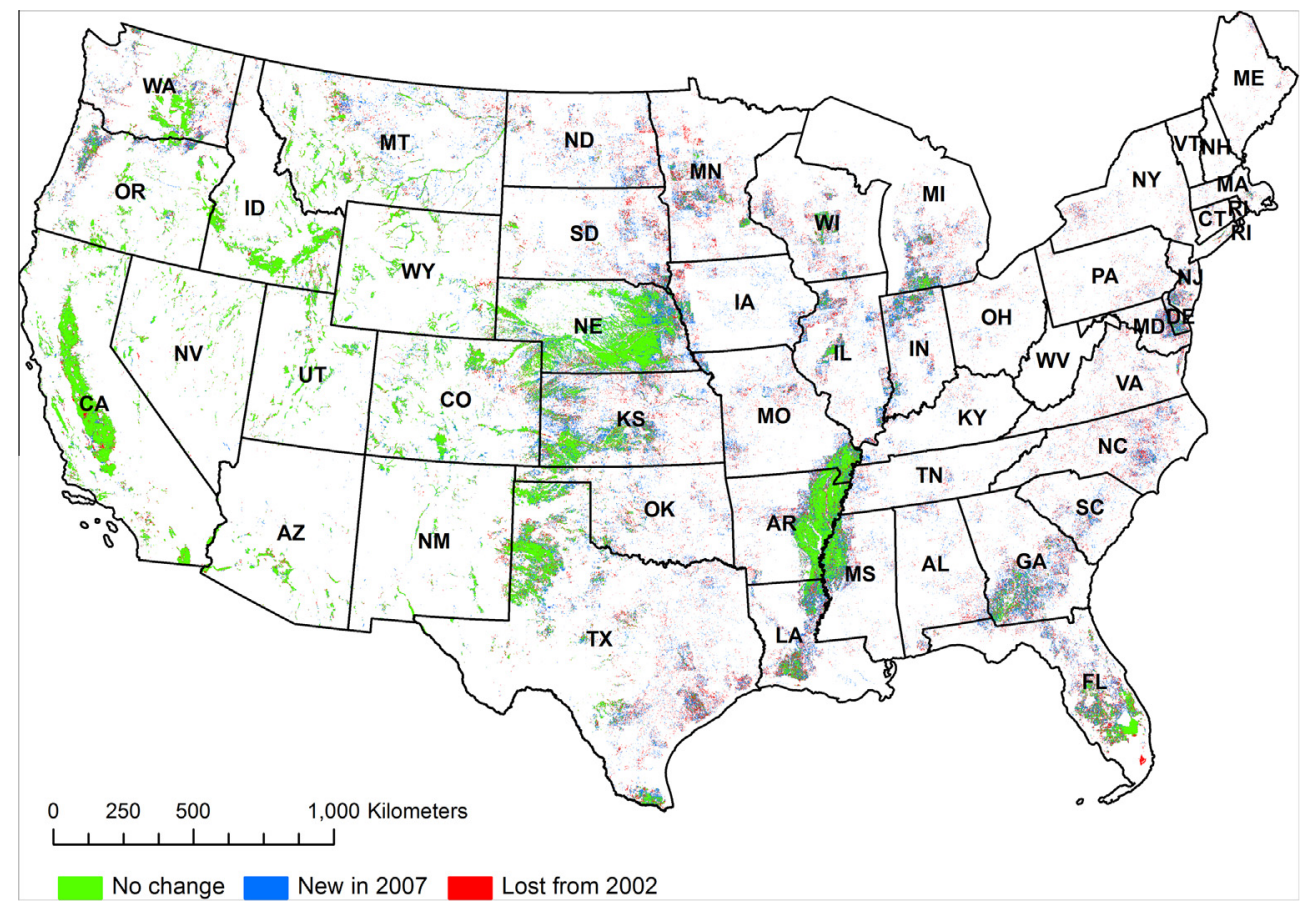

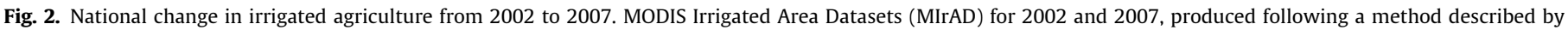
Pervez and Brown (2010), were used to create this change map.

Table 4

Change in irrigated areas from 2002 to 2007 calculated from the MIrAD-US within the top twelve irrigated states.

\begin{tabular}{|c|c|c|c|c|c|c|c|c|c|}
\hline \multirow[t]{2}{*}{ State } & \multicolumn{2}{|c|}{ Irrigated areas in ha } & \multicolumn{2}{|c|}{ Common areas between 2007 and 2002} & \multicolumn{2}{|c|}{ New in 2007} & \multicolumn{2}{|c|}{ Lost from 2002} & \multirow[t]{2}{*}{ Net change in $\%$} \\
\hline & 2007 & 2002 & in ha & $\%$ & in ha & $\%$ & in ha & $\%$ & \\
\hline $\mathrm{NE}$ & $3,682,575$ & $3,166,575$ & $2,300,156$ & 72.6 & $1,382,419$ & 43.7 & 866,419 & 27.4 & 16.3 \\
\hline $\mathrm{CA}$ & $3,236,513$ & $3,507,544$ & $2,721,838$ & 77.6 & 514,675 & 14.7 & 785,706 & 22.4 & -7.7 \\
\hline TX & $2,027,281$ & $2,047,050$ & $1,035,275$ & 50.6 & 992,006 & 48.5 & $1,011,775$ & 49.4 & -1.0 \\
\hline $\mathrm{AR}$ & $1,886,750$ & $1,780,194$ & $1,136,031$ & 63.8 & 750,719 & 42.2 & 644,163 & 36.2 & 6.0 \\
\hline ID & $1,348,000$ & $1,346,800$ & $1,032,500$ & 76.7 & 315,500 & 23.4 & 314,300 & 23.3 & 0.1 \\
\hline KS & $1,175,963$ & $1,115,881$ & 480,575 & 43.1 & 695,388 & 62.3 & 635,306 & 56.9 & 5.4 \\
\hline $\mathrm{CO}$ & $1,138,719$ & $1,050,569$ & 682,231 & 64.9 & 456,488 & 43.5 & 368,338 & 35.1 & 8.4 \\
\hline MT & 816,513 & 791,381 & 449,138 & 56.8 & 367,375 & 46.4 & 342,244 & 43.2 & 3.2 \\
\hline OR & 735,619 & 743,188 & 468,994 & 63.1 & 266,625 & 35.9 & 274,194 & 36.9 & -1.0 \\
\hline WA & 716,350 & 756,031 & 489,688 & 64.8 & 226,663 & 30.0 & 266,344 & 35.2 & -5.2 \\
\hline $\mathrm{FL}$ & 620,981 & 743,881 & 300,881 & 40.4 & 320,100 & 43.0 & 443,000 & 59.6 & -16.5 \\
\hline MS & 597,450 & 501,094 & 244,400 & 48.8 & 353,050 & 70.5 & 256,694 & 51.2 & 19.2 \\
\hline WY & 551,169 & 548,856 & 391,881 & 71.4 & 159,288 & 29.0 & 156,975 & 28.6 & 0.4 \\
\hline MO & 533,025 & 443,519 & 212,406 & 47.9 & 320,619 & 72.3 & 231,113 & 52.1 & 20.2 \\
\hline
\end{tabular}

Walla Walla counties in the west. In Oregon, irrigated areas were found relatively more dynamic in Clackamas, Linn, Umatilla and Yamhill counties with a statewide net loss of $1 \%$. Irrigation in Idaho was very stable during this period $-77 \%$ of irrigation remained unchanged and a minor amount $(0.1 \%)$ of overall net increase was observed.

The spatial patterns of irrigated area change between 2002 and 2007 were comparatively more dynamic in Florida, Kansas, Missouri, Mississippi, and Texas. All of these states had $50 \%$ or less unchanged irrigated areas (Table 4). In Kansas around 43\% irrigated areas were unchanged between 2007 and 2002. There were around $62 \%$ new irrigated areas in 2007 and 57\% loss in irrigated areas from 2002 resulted in 5.4\% net increase in irrigated areas in Kansas. Across Texas, the state with the third largest irrigated area, half of the irrigated areas remained unchanged spatially with an insignificant $1 \%$ net loss in 2007.

As depicted in Fig. 2, irrigation in the western U.S. showed greater spatial consistency through time than the irrigation in the eastern states. Around $66 \%$ of the irrigated areas from 17 Western states (ten of which are showed in Table 4; Nebraska, California, Texas, Idaho, Kansas, Colorado, Montana, Oregon, Washington, and Wyoming) were unchanged compared to only $41 \%$ unchanged irrigated areas across the remaining 31 states. Note: irrigated agriculture was not modeled for Alaska or Hawaii.

\subsubsection{Change in irrigated area across the HPA}

The land area showing irrigation fed by groundwater from the HPA showed more than double the national net increase of $3 \%$. From 2002 to 2007, the net change of irrigated lands increased approximately 519 thousand ha or $8.7 \%$ (Table 5). The MIrAD-US model revealed that 3.87 million ha (64\%) of irrigated cropland remained stable during this five-year period. This regional change in land use and agricultural intensity is in contrast to a national trend of decreasing cropland area over the past 30 years. Nationally, cropland used for crops has declined somewhat unevenly since 1982. From 2002 to 2007, cropland used for crops fell just over 2 
Table 5

Irrigated area and change by state within the HPA calculated from the MIrAD-US for 2002 and 2007 (sorted in descending order by ha irrigated in 2007).

\begin{tabular}{|c|c|c|c|c|c|c|c|c|c|}
\hline \multirow[t]{2}{*}{ State } & \multicolumn{2}{|c|}{ Irrigated area in ha } & \multicolumn{2}{|c|}{ Common area between 2007 and 2002} & \multicolumn{2}{|c|}{ New in 2007} & \multicolumn{2}{|c|}{ Lost from 2002} & \multirow[t]{2}{*}{ Net change in $\%$} \\
\hline & 2007 & 2002 & in ha & $\%$ & in ha & $\%$ & in ha & $\%$ & \\
\hline NE & $3,422,013$ & $2,942,856$ & $2,220,438$ & 75.5 & $1,201,575$ & 40.8 & 722,419 & 24.5 & 16.3 \\
\hline TX & $1,469,288$ & $1,451,419$ & 871,469 & 60.0 & 597,819 & 41.2 & 579,950 & 40.0 & 1.2 \\
\hline KS & $1,022,581$ & 969,206 & 454,894 & 46.9 & 567,688 & 58.6 & 514,313 & 53.1 & 5.5 \\
\hline $\mathrm{CO}$ & 270,656 & 270,413 & 138,400 & 51.2 & 132,256 & 48.9 & 132,013 & 48.8 & 0.1 \\
\hline WY & 111,144 & 116,644 & 70,500 & 60.4 & 40,644 & 34.8 & 46,144 & 39.6 & -4.7 \\
\hline OK & 105,406 & 103,850 & 51,113 & 49.2 & 54,294 & 52.3 & 52,738 & 50.8 & 1.5 \\
\hline NM & 96,525 & 125,531 & 66,206 & 52.7 & 30,319 & 24.2 & 59,325 & 47.3 & -23.1 \\
\hline SD & 7,400 & 5,469 & 1,794 & 32.8 & 5,606 & 102.5 & 3,675 & 67.2 & 35.3 \\
\hline Total & $6,505,012$ & $5,985,387$ & $3,874,812$ & 64.7 & $2,630,200$ & 43.9 & $2,110,575$ & 35.3 & 8.7 \\
\hline
\end{tabular}

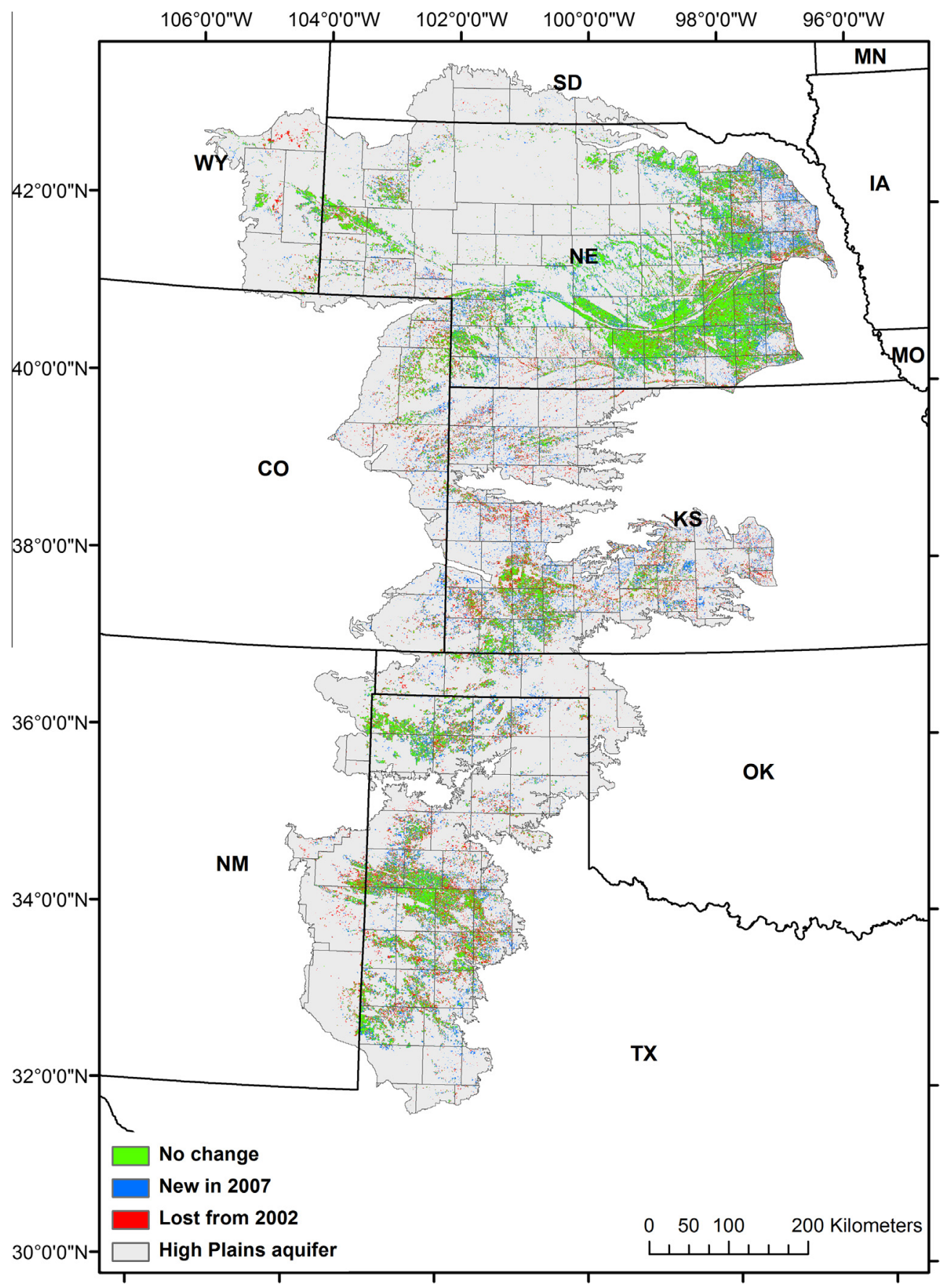

Fig. 3. Change in irrigated agriculture between 2002 and 2007 across the HPA derived from MIrAD-US 2002 and 2007. 
million ha to 136 million ha (or a loss of 5 million acres to 335 million acres) (Nickerson et al., 2011).

Nebraska overlays not only the largest portion of the HPA, but benefits from approximately two thirds of the aquifer's total water storage capacity (Johnson et al., 2011). From 2002 to 2007, the area in Nebraska above the HPA depicted the greatest increase in irrigated cropland area (479 thousand ha or net $+16.3 \%$ ) and also had the largest area of stable irrigated lands within the aquifer (over 2.2 million ha or 75.5\%) (Table 5). MIrAD-US showed that a large portion of the irrigation increase in 2007 occurred in northeast Nebraska (Fig. 3), primarily in the Lower Elkhorn, Lower Platte North, and Lower Loup natural resource districts.

Further south, irrigated areas fed by the HPA in Kansas and Texas showed smaller expansion with net changes of $1.2 \%$ and 5.5\%, respectively (Fig. 3; Table 5). Other states with much smaller total irrigated area supported by the aquifer did not change as drastically. Colorado and Oklahoma showed net increases of $0.1 \%$ and $1.5 \%$, respectively. Although South Dakota showed a net increase of $35.3 \%$, this represented only 2 thousand ha. Two states showed overall decreases in irrigated area, Wyoming and New Mexico decreased by $-4.7 \%$ and $-23.1 \%$. Neither state has much cropland area within the HPA, so these decreases had minimal overall effect.

\section{Discussion}

\subsection{Underlying causal factors in irrigation change in the HPA}

The causes for recent irrigation expansion are complex and merit discussion. Similarly to historical irrigation expansion, it is likely that multiple factors underpin recent changes in regional irrigated area. Gollehon and Quinby (2000) summarized causes contributing to the historical rise in irrigation use across the American West during the early and mid-twentieth century including increasing crop yields on the intensive margin to raise farm revenue, federal policies to develop water supplies, development of new groundwater mining and sprinkler technologies, and the rising demand for farm products. Although not an exhaustive discussion, we present multiple reasons for irrigation expansion in the HPA including: economic incentives such as crop pricing and land values, the demand for corn related to development of biofuels, government policies related to water or land use, and land availability. Regional climate fluctuations might also contribute to interannual dynamics of irrigation land use.

Historically, cropping shifts across the HPA is attributed to the cattle industry (Hudson, 1994). During the first part of the twentieth century, dominant crops were mainly wheat, alfalfa, and sorghum shifting to more corn and soybeans after the 1950s. Corn requires more water delivered at key times to increase yields so it appears the widespread use of pump irrigation contributed to large increases in corn cropped area in the semiarid central Plains (Dennehy et al., 2002). Studies have attributed increases in both irrigation and in growing corn to the demand for corn as livestock feed (Dennehy et al., 2002) and, more recently, as the main feedstock for ethanol production (Wallander et al., 2011).

Since 2000, crop commodity prices rose dramatically (Fig. 4) and these price increases have affected land use and cropping decisions in the agricultural community (Atkinson et al., 2011; Lubowski et al., 2008; Swinton et al., 2011). Average national crop prices rose between 2002 to 2007 by $81 \%, 82 \%, 76 \%$, and $90 \%$ for corn, soybeans, sorghum, and wheat, respectively (Fig. 4) (U.S. Department of Agriculture, 2012). In terms of area, corn is the dominant irrigated crop in the HPA (Fig. 4 and Table 6) even though there is substantial year to year variability. Comparing 2002 to 2007, there was a large increase in the number of harvested ha of both irrigated and non-irrigated corn (Table 6). In fact, corn hit a maximum harvested area (for the decade) in 2007. Table 6 shows the relative proportion of each crop type to the irrigated areal total. Harvested irrigated corn was the dominant irrigated crop in the HPA, making up 45 and $47 \%$ in 2002 and 2007, respectively. Actually, total corn increased during this period by 0.88 million ha. Prior studies have discussed expansion of corn production related to an increase in corn-based ethanol production (Fabiosa et al., 2009; Wallander et al., 2011). We also infer a connection between the expansion of irrigation across the HPA and increasing demand for corn for ethanol. Corn is the common feedstock for most of the U.S. ethanol production (Searchinger and Heimlich, 2009). From 2001 to 2010, the use of corn for ethanol nationally increased dramatically due to the mandate in the Energy Policy Act of 2005 to increase the amount of renewable fuels in the U.S. fuel supply. This law significantly increased the production of corn ethanol (Nickerson et al., 2011). Wallander et al. (2011) describe a complex array of recently shifting cropping patterns across the U.S. related to the ethanol industry including increasing corn production on farms that were formerly soybean producers.

Fig. 5 shows the locations of 47 ethanol plants in and adjacent to the HPA during the periods pre-2002 (triangle), 2002-2007 (circle), and post-2007 (square) along with the irrigation status classes shown in Fig. 3. Nebraska had the largest number of ethanol plants (24) of all HPA states and over half (13) were established between 2002 and 2007, while four additional plants were brought online in 2008 (Nebraska Ethanol Board, 2012). Our research does not show how much of the $16.3 \%$ expansion of irrigation in Nebraska was dedicated to growing corn.

During this same historical period, land values also rose dramatically influencing land use decisions. In Nebraska, reported land values rose $22 \%$ from $\$ 734$ to $\$ 892$ per acre (deflated average over four land types: see Appendix Table 2 in (Johnson and Van NewKirk, 2012)) from 2002 to 2007. Large increases of 57\%, 60\%, and $51 \%$ for the same period were seen for dryland cropland (no irrigation potential), dryland cropland (irrigation potential), and center pivot irrigated cropland, respectively. Comparatively larger increases in land values were seen in Texas, where the price per acre rose $124 \%$ from 2002 to 2007 (from $\$ 974$ to $\$ 2190$ for the Texas Statewide Weighted Average Index Price per Acre; Gilliland et al., 2008).

Government water policy apparently has played a role in the HPA irrigation expansion. In Nebraska, for example, changes in state water policy recently occurred. In 2004, Legislative Bill 962 (LB962) was signed into law by the Nebraska Legislature establishing moratoria on irrigation growth in water resource districts where water was designated by the Nebraska Department of Natural Resources (NDNR) as fully and/or over-appropriated. In 2004, districts in the eastern third of Nebraska were not yet subject to moratoria. This policy apparently spurred producers to establish new wells for irrigation and thereby expand the amount of land under irrigation. Fig. 6 shows new irrigation wells established within the NDNR districts covering the HPA exceeding 1200 per year during 2002 through 2005, and peaking at over 1600 in 2004 (Nebraska Department of Natural Resources, 2012a).

Intra-annual variability in irrigated area is likely linked to regional growing season climate conditions. When periods of widespread soil moisture deficits occur, farmers equipped for irrigation are likely to irrigate. The region's drought history might reveal possible climate factors for the change in irrigated area from 2002 and 2007. National maps of drought severity (Fig. 7) for late summer 2002 and 2007 show key climatic differences between these two years (Svoboda et al., 2002). In the summer growing season of 2002, a large part of the HPA experienced severe, extreme and even exceptional drought conditions, (Fig. 7a-c). In contrast, the summer growing season conditions of 2007 were generally 

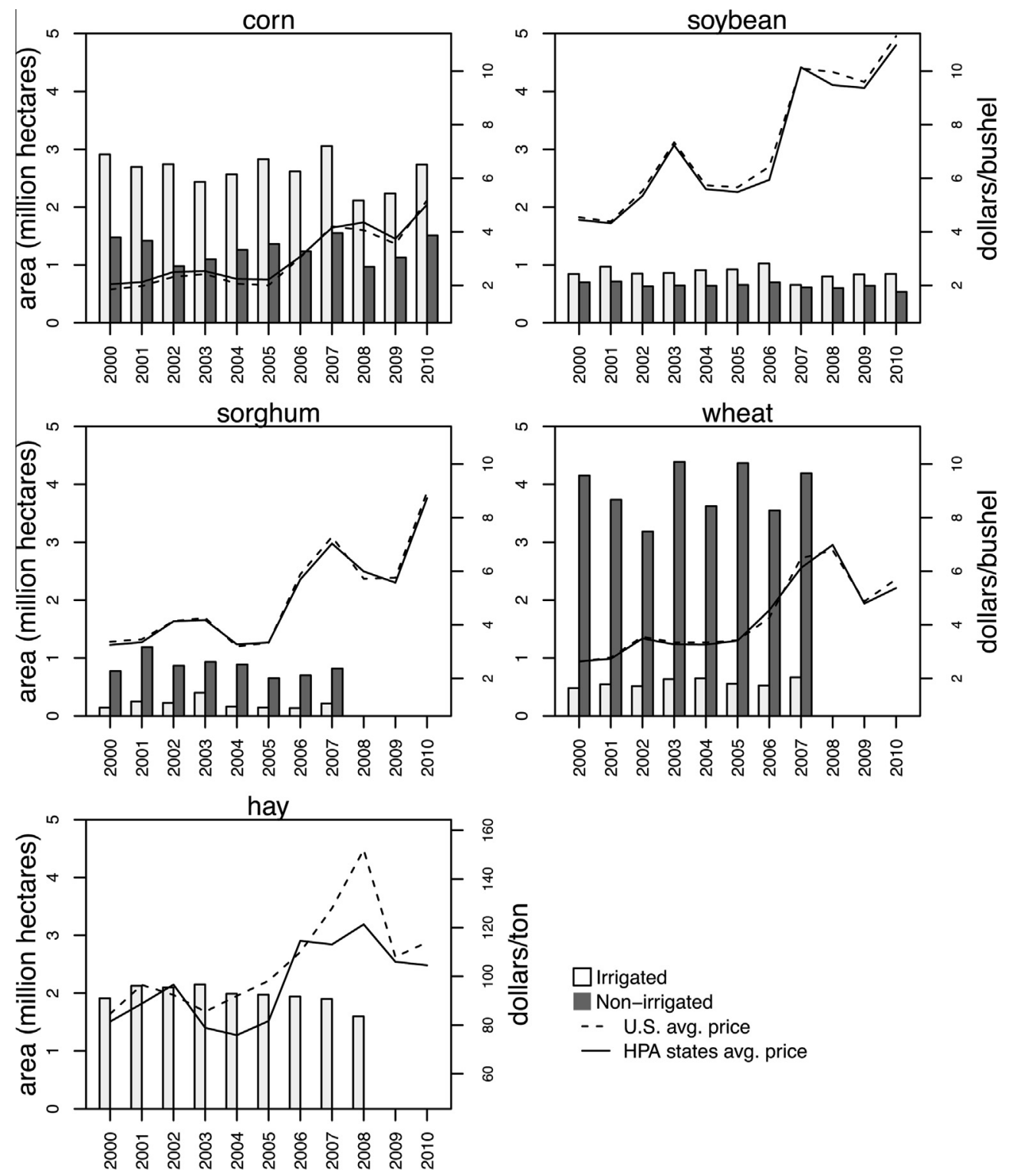

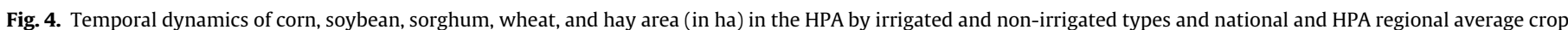

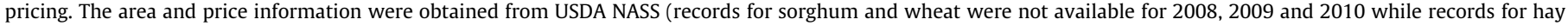

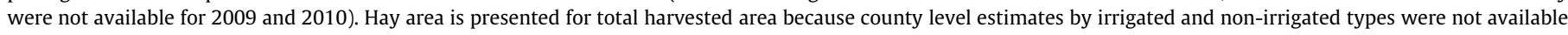
(U.S. Department of Agriculture, 2012).

Table 6

Harvested area of dominant irrigated and non-irrigated crops within counties in the HPA (U.S. Department of Agriculture, 2012).

\begin{tabular}{|c|c|c|c|c|c|c|}
\hline & & \multicolumn{2}{|l|}{2002} & \multicolumn{2}{|l|}{2007} & \multirow{2}{*}{$\begin{array}{l}\text { 2002-2007 Change } \\
\text { million ha }\end{array}$} \\
\hline & & million ha & $\%$ of total area & million ha & $\%$ of total area & \\
\hline \multirow[t]{3}{*}{ Corn } & Irrigated & 2.74 & \multirow[t]{3}{*}{45.78} & 3.06 & \multirow[t]{3}{*}{47.04} & 0.31 \\
\hline & Non-irrigated & 0.98 & & 1.55 & & 0.57 \\
\hline & Total & 3.72 & & 4.61 & & 0.88 \\
\hline \multirow[t]{3}{*}{ Soybeans } & Irrigated & 0.85 & \multirow[t]{3}{*}{14.20} & 0.66 & \multirow[t]{3}{*}{10.14} & -0.20 \\
\hline & Non-irrigated & 0.63 & & 0.70 & & 0.07 \\
\hline & Total & 1.48 & & 1.36 & & -0.13 \\
\hline \multirow[t]{3}{*}{ Sorghum } & Irrigated & 0.23 & \multirow[t]{3}{*}{3.84} & 0.21 & \multirow[t]{3}{*}{3.23} & -0.01 \\
\hline & Non-irrigated & 0.87 & & 0.82 & & -0.05 \\
\hline & Total & 1.09 & & 1.03 & & -0.06 \\
\hline \multirow[t]{3}{*}{ Wheat } & Irrigated & 0.51 & \multirow[t]{3}{*}{8.52} & 0.67 & \multirow[t]{3}{*}{10.30} & 0.15 \\
\hline & Non-irrigated & 3.18 & & 4.19 & & 1.01 \\
\hline & Total & 3.70 & & 4.86 & & 1.16 \\
\hline Hay & Total & 2.10 & & 1.90 & & -0.20 \\
\hline
\end{tabular}




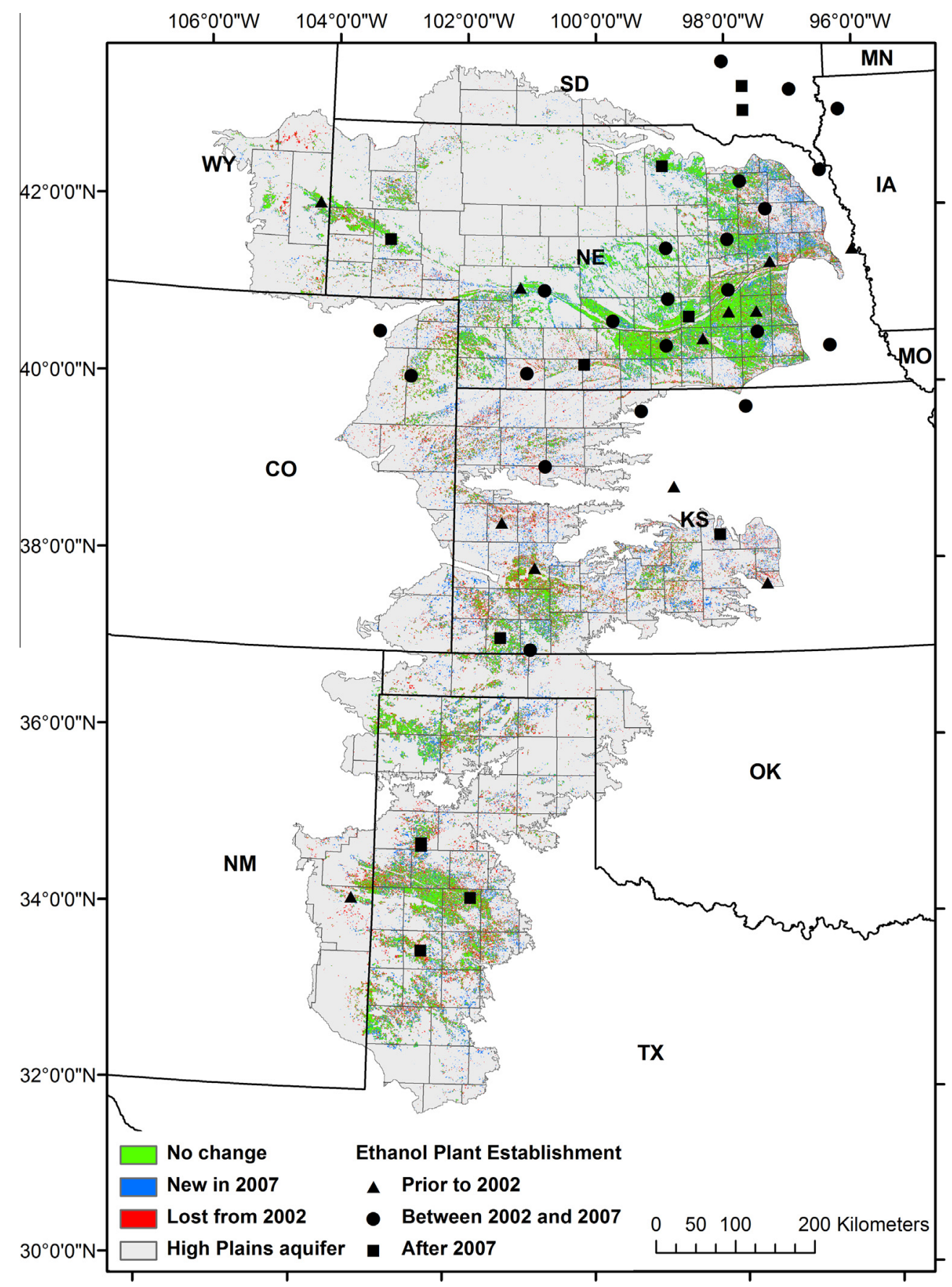

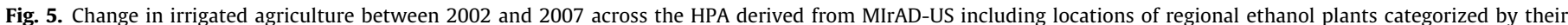
establishment year.

much wetter and the HPA region did not experience similar severity of drought conditions (Fig. 7d-f). In fact, the U.S. Weather Review (U.S. Department of Commerce and U.S. Department of Agriculture, 2008) showed that many states overlying the HPA (Nebraska, Kansas, Oklahoma, and Texas) showed much above normal precipitation in 2007.

The climate conditions in 2007 appeared more favorable to growing rainfed crops in this region and this is supported by the harvested area statistics for these two years (U.S. Department of Agriculture, 2012) (Fig. 4). The combined harvested area for four non-irrigated crops (corn, soybeans, sorghum, and wheat) changed from 5.66 to 7.26 million ha, or a $28 \%$ increase in harvested area from 2002 for these four crops (Table 6). Perhaps counter to drought influences, irrigated area was smaller in 2002, a year where the HPA was dominated by a drought, than in 2007, a year with far more favorable moisture available for crop growth. In 2002, the harvested area for irrigated crops (corn, soybeans, sorghum, and wheat) in the HPA was 4.33 million ha and in 2007, the area covered was 4.59 million ha, an increase of 260,000 ha or approximately $6 \%$. The field crop area statistics support evidence that irrigation water use was likely higher in 2007, despite a comparatively favorable climate for rainfed crops in the region.

The availability of previously non-cultivated land (e.g., lands set aside for conservation programs) might be indirectly associated with increases in irrigated cropland, potentially providing land to be converted into crop production. Available lands for conversion 


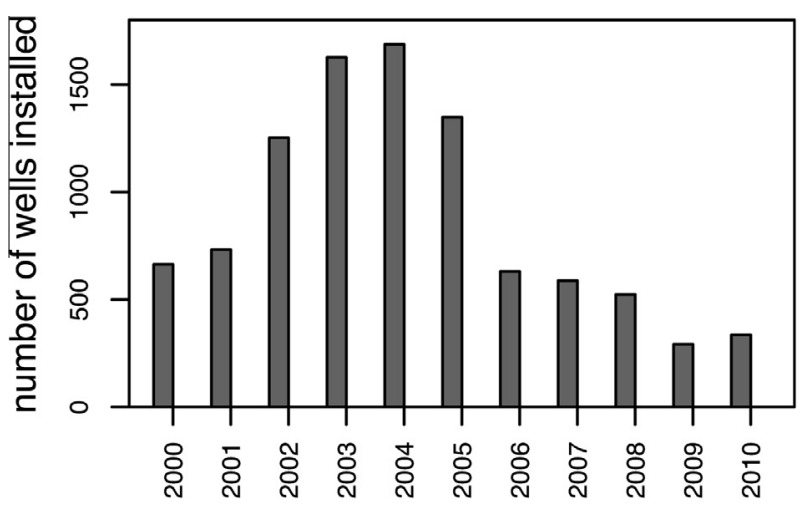

Fig. 6. New irrigation wells in Nebraska, 2000-2010.

to irrigated cropland would include existing rainfed croplands and other non-cropped lands (e.g., grasslands, shrublands, wetlands, and forests) some of which would be part of the USDA sponsored

(a)

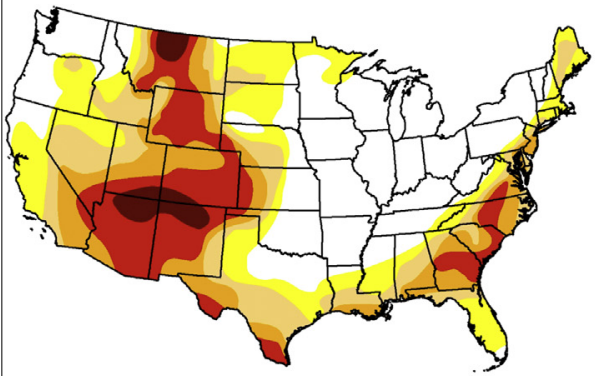

(b)

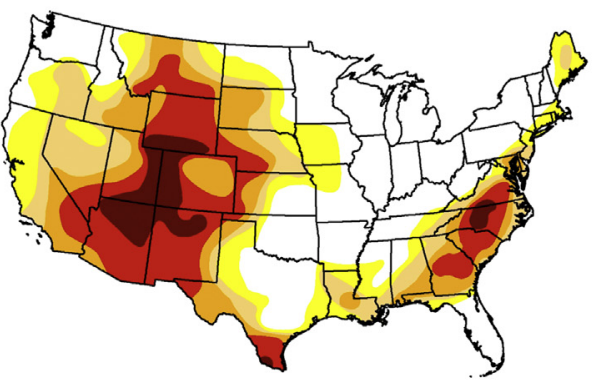

(c)

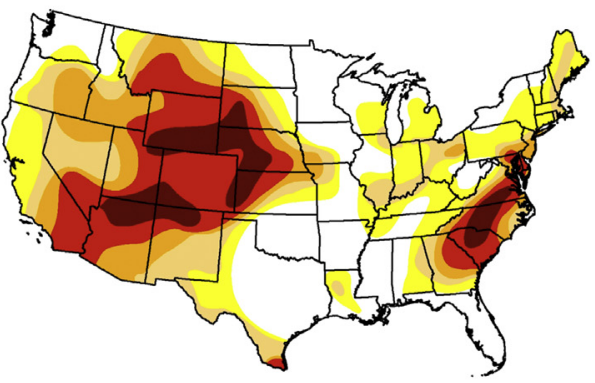

Conservation Reserve Program (CRP). Regional land conversion patterns in the HPA are beyond the scope of this discussion, but this is an area for future investigation.

\section{Conclusions}

This study provides results from both a national effort to map agricultural land use change across the conterminous U.S. and a regional analysis of groundwater-fed irrigation change within the HPA, the most intensively used aquifer in the central U.S. We summarized our national modeling methodology and presented accuracy results for three regions where appropriate ground truth data were acquired. Overall accuracy was $92 \%, 89 \%$, and $94 \%$ for California, the Great Plains, and the ESPA region in Idaho, respectively.

In the regionally-focused part of the study, we provided detailed geospatial information about irrigation expansion (more than $8 \%$ ) from 2002 to 2007 across the HPA. In fact, over $95 \%$ of the net national expansion in irrigated agriculture during this

(d)

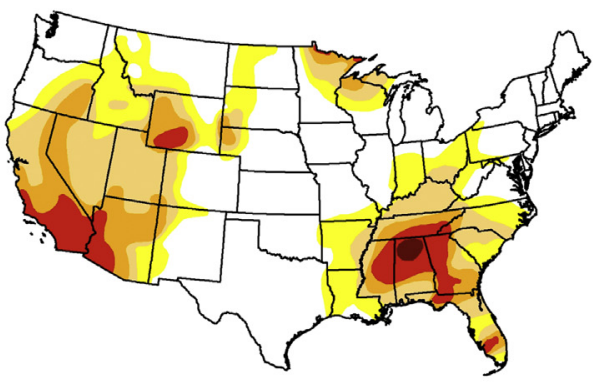

(e)

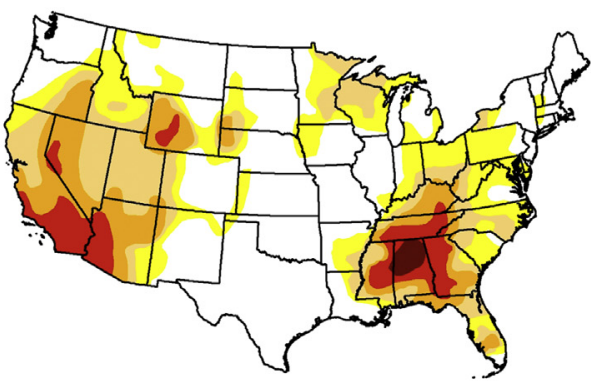

(f)

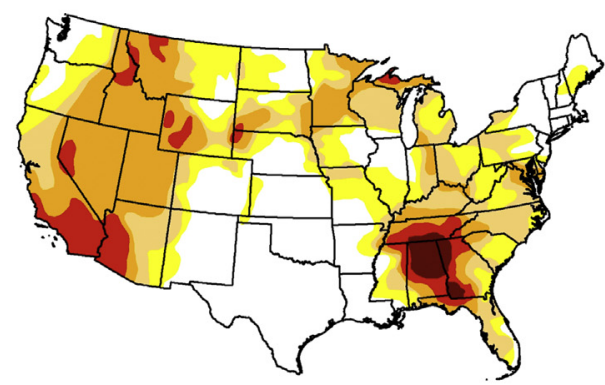

Drought Severity

Do - Abnormally Dry

D1 Drought - Moderate

D2 Drought - Severe

D3 Drought - Extreme

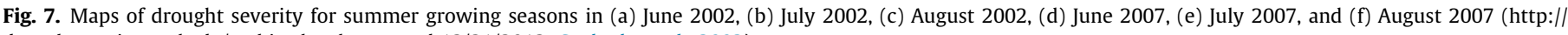
droughtmonitor.unl.edu/archive.html, accessed 12/21/2012; Svoboda et al., 2002). 
period overlays this aquifer. We discussed complex reasons for irrigation expansion. Although a significant proportion of the aquifer appears to have stable water supply (primarily under Nebraska), increased use of the groundwater may not be sustainable in the long run. Areas of Texas and western Kansas have shown reductions in water levels exceeding 150 feet from predevelopment to 2009 (McGuire, 2011). It does not seem likely that these areas can continue to support future irrigation expansion at this rate.

A complicated picture of land use change has emerged relating irrigation expansion linked with rising crop commodity prices, water policy, ethanol development, and other factors. While the reasons are complex, it is clear that a detailed monitoring of irrigation status into the future will contribute to improving understanding of water use, water supply, and the sustainability of the entire aquifer.

The MIrAD-US 2002- and 2007-era geospatial data sets are currently available for download from the USGS Early Warning and Environmental Monitoring website (http://earlywarning.usgs.gov/ USirrigation/). Looking forward, future production of the MIrADUS for upcoming five-year eras (e.g., 2012, 2017, and so on) is desirable, provided the availability of model inputs. In early 2014, the USDA plans to release updated agricultural statistics for all the counties in the U.S. including the area of irrigated lands, in their 2012 Census of Agriculture. At the time of this writing, the MODIS instruments aboard the Terra and Aqua satellite platforms are operating and continuing to collect optical data. The 2012 growing season eMODIS NDVI data are available (online at http://dds.cr.usgs.gov/emodis/CONUS/) from which to calculate an annual peak. The next update of the NLCD will be 2011-era land cover and has a planned release date of December 2013.

\section{Acknowledgements}

Funding support for this work was provided by the USGS Land Change Science and Land Remote Sensing programs under the Climate and Land Use Change Mission Area. We want to thank R. Auch and anonymous reviewers for their valuable review comments. R. Zelt from the USGS Nebraska Water Science Center provided useful insight and recommendations for research directions. We are also grateful to our irrigation ground-truth data providers: W.J. Kramber and M. Wilkins, Idaho Dept. of Water Resources; B. Kurz and S.K. Seelan, University of North Dakota. Any use of trade, product, or firm names is for descriptive purposes only and does not imply endorsement by the U.S. Government.

\section{References}

Adegoke, J.O., Pielke Sr., R.A., Eastman, J., Mahmood, R., Hubbard, K.G., 2003. Impact of irrigation on midsummer surface fluxes and temperature under dry synoptic conditions: a regional atmospheric model study of the U.S. high plains. Mon. Weather Rev. 131, 556-564.

Aparicio, N., Villegas, D., Casadesus, J., Araus, J.L., Royo, C., 2000. Spectral vegetation indices as nondestructive tools for determining durum wheat yield. Agron. J. 92, 83-91.

Atkinson, L.M., Romsdahl, R.J., Hill, M.J., 2011. Future participation in the conservation reserve program in North Dakota. Great Plains Res. 21, 203-214.

Brown, J.F., Pervez, M.S., Maxwell, S.K., 2009. Mapping irrigated lands across the United States using MODIS satellite imagery. In: Thenkabail, P. (Ed.), Remote Sensing of Global Croplands for Food Security. Taylor \& Francis, Boca Raton, Florida, pp. 177-198.

Dennehy, K.F., Litke, D.W., McMahon, P.B., 2002. The High Plains Aquifer, USA Groundwater Development and Sustainability, Geological Society Special Publication, pp. 99-119.

Evans, R.G., Sadler, E.J., 2008. Methods and technologies to improve efficiency of water use. Water Resour. Res, 44

Fabiosa, J., Beghin, J.C., Dong, F., Elobeid, A., Tokgoz, S., Yu, T.H., 2009. Land Allocation Effects of the Global Ethanol Surge: Predictions from the International FAPRI Model. 09-WP 488. Center for Agricultural and Rura Development, Iowa State University, Ames, Iowa.
Fry, J.A., Xian, G., Jin, S., Dewitz, J.A., Homer, C.G., Yang, L., Barnes, C.A., Herold, N.D. Wickham, J.D., 2011. Completion of the 2006 national land cover database for the conterminous United States. Photogram. Eng. Remote Sens. 77, 858-864.

Gilliland, C.E., Pachchigar, N., Singh, S., 2008. Texas Land Market Developments 2007. College Station, TX. <http://recenter.tamu.edu/pubs/> (accessed 28.02.13).

Gollehon, N., Quinby, W., 2000. Irrigation in the American West: area, water and economic activity. Int. J. Water Resour. Dev. 16, 187-195.

High Plains Study Council, 1982. Summary of Results of the Ogallala Aquifer Regional Study, with Recommendations to the Secretary of Commerce and Congress. Economic Development Administration, Washington, DC.

Hudson, J.C., 1994. Making the Corn Belt: A Geographical History of MiddleWestern Agriculture. Indiana University Press, Bloomington, IN.

Jenkerson, C., Maiersperger, T., Schmidt, G., 2010. eMODIS: A User-Friendly Data Source. U.S. Geological Survey Open-File Report 2010-1055, Reston, Virginia, $<$ http://pubs.usgs.gov/of/2010/1055/>. (accessed on 28.02.2013)..

Ji, L., Peters, A.J., 2003. Assessing vegetation response to drought in the northern Great Plains using vegetation and drought indices. Remote Sens. Environ. 87, 85-98.

Johnson, B., Van NewKirk, S., 2012. Nebraska Farm Real Estate Market Highlights 2010-2011. Department of Agricultural Economics, University of NebraskaLincoln, Lincoln, Nebraska.

Johnson, B., Thompson, C., Giri, A., Van NewKirk, S., 2011. Nebraska Irrigation Fact Sheet. Report No. 190. Department of Agricultural Economics, University of Nebraska-Lincoln, Lincoln, Nebraska. <http:// agecon.unl.edu/c/document_library/get_file?uuid=a9fcd902-4da9-4c3f-9e04c8b56a9b22c7\&groupld=2369805\&.pdf > (accessed 13.09.12).

Jones, J., 2010. California's Drought of 2007-2009: An Overview. State of California, California Department of Water Resources, Sacramento, California. <http:// www.water.ca.gov/drought>.

Kawabata, A., Ichii, K., Yamaguchi, Y., 2001. Global monitoring of interannual changes in vegetation activities using NDVI and its relationships to temperature and precipitation. Int. J. Remote Sens. 22, 1377-1382.

Kraak, M., Ormeling, F., 1996. Cartography, Visualization of Spatial Data. Addision Wesley Longman Limited, Essex, England.

Lubowski, R.N., Plantinga, A.J., Stavins, R.N., 2008. What drives land-use change in the United States? A national analysis of landowner decisions. Land Econ. 84 529-550.

Matson, P.A., Parton, W.J., Power, A.G., Swift, M.J., 1997. Agricultural intensification and ecosystem properties. Science 277, 504-509.

Maupin, M., Barber, N., 2005. Estimated Withdrawals from Principal Aquifers in the United States. Circular 1279. U.S. Geological Survey.

McGuire, V.L., 2011. Water-level Changes in the High Plains Aquifer, Predevelopment to 2009, 2007-08, and 2008-09, and Change in Water in Storage, Predevelopment to 2009. Scientific Investigations Report 2011-5089. U.S. Geological Survey. <http://pubs.usgs.gov/sir/2011/5089/> (accessed 02.09.12).

Migliaccio, K.W., 2008. Sustainability of Agriculture in Miami-Data County: Considering Water Supply. IFAS Extension Report ABE380. University of Florida.

Moody, A., Woodcock, C.E., 1994. Scale-dependent errors in the estimation of landcover proportions: implications for global land-cover datasets. Photogram. Eng. Remote Sens. 60, 585-594.

Moody, A., Woodcock, C.E., 1995. The influence of scale and the spatial characteristics of landscapes on land-cover mapping using remote sensing. Landscape Ecol. 10, 363-379.

National Oceanic and Atmospheric Administration, 2007. State of the Climate: National Overview for 2007. Department of Commerce. <http:/ www.ncdc.noaa.gov/sotc/national/2007/13> (accessed 28.04.12).

Nebraska Department of Natural Resources, 2012a. New Irrigation Wells per Year 1993-2011. <http://dnr.ne.gov/docs/DNR_BrochureLists.html> (accessed 23.07.12)

Nebraska Department of Natural Resources, 2012b. Registered Irrigation Wells: Between 1972 and 2011 by Natural Resources Districts. Lincoln, Nebraska. <http://dnr.ne.gov/docs/DNR_BrochureList.html> (accessed 03.12.12).

Nebraska Ethanol Board, 2012. Nebraska's Ethanol Industry. <http://www. ne-ethanol.org/? page=industry> (accessed 17.09.12).

Nickerson, C., Ebel, R., Borchers, A., Carraizo, F., 2011. Major Uses of Land in the United States, 2007. EIB 89. U.S. Department of Agriculture, Economic Research Service.

Ozdogan, M., Gutman, G., 2008. A new methodology to map irrigated areas using multi-temporal MODIS and ancillary data: an application example in the continental US. Remote Sens. Environ. 112, 3520-3537.

Pervez, M.S., Brown, J.F., 2010. Mapping irrigated lands at 250-m scale by merging MODIS data and national agricultural statistics. Remote Sens. 2, 2388-2412.

Peterson, J.M., Bernardo, D.J., 2003. High plains regional aquifer study revisited: a 20-year retrospective for western Kansas. Great Plains Res. 13, 179-197.

Puma, M.J., Cook, B.I., 2010. Effects of irrigation on global climate during the 20th century. J. Geophys. Res. D: Atmos. 115.

Rundquist, B.C., Harrington, J.A.J., Goodin, D.G., 2000. Mesoscale satellite bioclimatology. Prof. Geogr. 52, 331-344.

Sacks, W.J., Cook, B.I., Buenning, N., Levis, S., Helkowski, J.H., 2009. Effects of global irrigation on the near-surface climate. Clim. Dyn. 33, 159-175.

Scanlon, B.R., Jolly, I., Sophocleous, M., Zhang, L., 2007. Global impacts of conversions from natural to agricultural ecosystems on water resources: quantity versus quality. Water Resour. Res. 43, W03437. 
Searchinger, T., Heimlich, R., 2009. Likely impacts of biofuel expansion on midwest land and water resources. Int. J. Biotechnol. 11, 127-149.

Shiklomanov, I.A., 2000. Appraisal and assessment of world water resources. Water Int. 25, 11-32.

Sophocleous, M., 2005. Groundwater recharge and sustainability in the High Plains Aquifer in Kansas, USA. Hydrogeol. J. 13, 351-365.

Svoboda, M., LeComte, D., Hayes, M., Heim, R., Gleason, K., Angel, J., Rippey, B., Tinker, R., Palecki, M., Stooksbury, D., Miskus, D., Stephens, S., 2002. The drought monitor. Bull. Am. Meteorol. Soc. 83, 1181-1190.

Swinton, S.M., Babcock, B.A., James, L.K., Bandaru, V., 2011. Higher US crop prices trigger little area expansion so marginal land for biofuel crops is limited. Energy Policy 39, 5254-5258.

Thenkabail, P., Biradar, C., Noojipady, P., Dheeravath, V., Li, Y., Velpuri, M., Gumma, M., Gangalakunta, O.R., Turral, H., Cai, X., Vithanage, J., Schull, M., Dutta, R., 2009. Global irrigated area map (GIAM), derived from remote sensing, for the end of the last millennium. Int. J. Remote Sens. 30, 3679-3733.

Townshend, J.R.G., Justice, C., 2002. Towards operational monitoring of terrestrial systems by moderate-resolution remote sensing. Remote Sens. Environ. 83, 351-359.

U.S. Department of Agriculture, 2004. 2002 Census of Agriculture: United States Summary and State Data. AC-02-A-51. U.S. Department of Agriculture.

U.S. Department of Agriculture, 2009a. 2007 Census of Agriculture: United States Summary and State Data. AC-07-A-51. U.S. Department of Agriculture.

U.S. Department of Agriculture, 2009b. Farm and Ranch Irrigation Survey (2008). AC-07-SS-1. U.S. Department of Agriculture.

U.S. Department of Agriculture, 2012. National Agricultural Statistics Service Quick Stats. <http://www.nass.usda.gov/Quick_Stats> (accessed 16.08.12)
U.S. Department of Commerce, U.S. Department of Agriculture, 2008. Weekly Weather and Crop Bulletin. Rocket Center, West Virginia. <http:// www.usda.gov/oce/waob/jawf/wwcb.html> (accessed 30.09.12).

Van Rompaey, A.J.J., Govers, G., 2002. Data quality and model complexity for regional scale soil erosion prediction. Int. J. Geogr. Inf. Sci. 16, 663-680.

Viard, T., Caumon, G., Lévy, B., 2011. Adjacent versus coincident representations of geospatial uncertainty: which promote better decisions? Comput. Geosci. 37 511-520.

Vörösmarty, C.J., Green, P., Salisbury, J., Lammers, R.B., 2000. Global water resources: vulnerability from climate change and population growth. Science 289, 284-288.

Wallander, S., Claassen, R., Nickerson, C., 2011. The Ethanol Decade: An Expansion of U.S. Corn Production, 2000-09. EIB 79. U.S. Department of Agriculture, Economic Research Service.

Wang, J., Rich, P.M., Price, K.P., 2003. Temporal responses of NDVI to precipitation and temperature in the central Great Plains, USA. Int. J. Remote Sens. 24, 2345 2364.

Wardlow, B.D., Egbert, S.L., 2008. Large-area crop mapping using time-series MODIS 250 m NDVI data: an assessment for the U.S. Central Great Plains. Remote Sens. Environ. 112, 1096-1116.

Wickham, J.D., Stehman, S.V., Fry, J.A., Smith, J.H., Homer, C.G., 2010. Thematic accuracy of the NLCD 2001 land cover for the conterminous United States. Remote Sens. Environ. 114, 1286-1296.

Wickham, J.D., Stehman, S.V., Gass, L., Dewitz, J., Fry, J.A., Wade, T.G., 2013. Accuracy assessment of NLCD 2006 land cover and impervious surface. Remote Sens. Environ. 130, 294-304.

Wulder, M.A., Hall, R.J., Coops, N.C., Franklin, S.E., 2004. High spatial resolution remotely sensed data for ecosystem characterization. Bioscience 54, 511-521. 